\title{
The Network of Financial Institutions and Capital Accumulation in Vas County in the Second Half of the $19^{\text {th }}$ Century
}

\begin{abstract}
The way financial institutions emerged in Hungary was just the inverse of the one followed in Western Europe. In Western Europe capital intensive banks developed first and savings banks rendering services to people with more modest financial means appeared later. In the second half of the $19^{\text {th }}$ century a new bank type (Credit mobilier) was created, which combined the commercial and development banking activities. In Hungary the first financial institution got established in 1842 as a company limited by shares, and the banks founded subsequent to 1867 fashioned their business policies in this vein. In Vas county, situated in West-Transdanubia, and in its county- seat, Szombathely, capital accumulation strengthened by leaps and bounds after a difficult start and the emergence of financial institutions was largely supported by the enactment of the Commercial Code in 1875. In the first business year following the crisis of 1873 already 16 banks and savings banks operated in Vas county, with the number of financial institutions reaching 27 by the turn of the century. Between 1874 and 1899 their number increased to almost two and a half times this figure, and in settlements with populations between one thousand and three thousand people two, in larger settlements three, and in the county seat five new financial institutions had been founded by the turn of the century. The increase in the initial capital saw a nearly eleven times increase, the balance sheet total expanded 6.3 times and the total cash turnover of Vas county financial institutions amounted to 178,414,263 Austro-Hungarian Krones in 1899 . Within the county's territory microregional money markets evolved. No data have so far been found regarding the turnover undoubtedly realised between such microregions for the time being.
\end{abstract}

Keywords: Vas county, Szombathely, savings bank, bank, capital accumulation

\section{Introduction and Precedents}

An attempt has already been made to showcase the economy of Vas county, one of the Western Transdanubian counties, during the age of the Dualism. ${ }^{1}$ However, the author used only a single source in his study when enumerating financial institutions, namely the master records of partnerships kept by the Registry Court, ${ }^{2}$ which definitely provide reliable data about foundations and mergers, but include extremely few economic data besides the development of the initial capital figures.

Although the change in the initial capital is a key data, it by no means reflects the turnover of the business or the split of the various business branches within. Lacking the balance sheet data and most of all the balance sheet total figures, the size of the initial capital cannot be interpreted properly, since a financial institution may have circulated cash several times as much as its initial capital in a business year. Furthermore, in many cases only $50 \%$ of the initial capital was actually paid up and savings banks or banks could realise earnings many times its initial capital.

1 Horváth, Ferenc: Vas megye közgazdasági viszonyai a dualizmus korában II. Vasi Szemle 34 (1980). 2. sz. 237249.

2 Magyar Nemzeti Levéltár Vas Megyei Levéltára. (hereinafter: MNL VaML) VII.1.h. A Szombathelyi Királyi Törvényszék iratai. Cégbíróság iratok. Társas cégjegyzék. [The Hungarian National Archives Vas County Archives. The documents of the Royal Regional Court of Szombathely. Registry Court documents. Partnership register. Hereinafter: Partnership register.] 
The development of financial institutions in Hungary was contrary to the process seen in Western Europe, where it was the capital intensive banks that emerged first and an already formed system of banks had been in operation by the time savings banks with much lower capital intensity proliferated. In contrast, in Hungary, the emergence of savings banks predated that of the banks by over two decades. The different paths resulted in different developmental trajectories.

In Western-Europe, the primary objective of savings banks was to allow people with more modest financial means to make interest-bearing deposits or to obtain smaller or larger loans, but it was also to make thousands of people get used to the simplest financial transactions by getting financially educated with the importance of savings in the focus, thereby consequently creating a uniform financial culture. These institutions, often featuring philanthropic traits, were initially involved in collecting deposits only. The first Hungarian savings banks were founded similarly to their Western-European peers, but later, copying the example of the savings bank founded in Pozsony [Bratislava, SK] in 1842 as a company limited by shares, every savings bank of the time shortly switched over to this company form. These, and all the financial institutions established subsequently, already shifted profits to the focus of their business policies. ${ }^{3}$ This required the Acts of $1840,{ }^{4}$ which opened the gates to founding companies limited by shares by granting permission to the shareholders to realise profits on the business. ${ }^{5}$ In 1848 already 36 savings banks were awaiting clients in Hungary, in Transdanubia such savings banks operated in Sopron, Veszprém, Pécs, Győr, Szekszárd, Nagykanizsa and, in Vas county, the only one was founded in 1844 in Köszeg. ${ }^{6}$

The Acts furthermore regulated the lines and operations of banks bearing much greater capital intensity than savings banks in detail. Among the lines of business, we could find lending, giro transfer, deposit and advance transactions, property loans and bill discounting. Banks were not allowed to collect deposits; they could only attract borrowed funds with the help of interestbearing certificates of deposit issued in proportion to their equities. ${ }^{7}$

Following 1850, the Neo-Absolutist public administration introduced the district system in the Hungarian Crown Country. The nine counties of Transdanubia ${ }^{8}$ belonged to the Soproncentred administrative unit in which the above-mentioned seven savings banks operated, five of them in county seats, and the two others in towns with larger market districts than county seats, i.e. it was in Köszeg, Vas county ${ }^{9}$ and in Nagykanizsa, Zala county that the first savings banks were founded.

In accordance with Section 994 of the Austrian Civil Code taking effect also in the Hungarian Crown Country on 1 May 1853 a 5\% interest could be collected on loans against

\footnotetext{
3 Jirkovsky, Sándor: Takarékpénztáraink és a miskolczi 1899. évi értekezlet. Közgazdasági Szemle 67 (1942) 42. 434.

4 Soós, László: Az Osztrák Nemzeti Bank. In: A Magyar Nemzeti Bank története I. Szerk. Bácskai Tamás. Közgazdasági és Jogi Könyvkiadó, Bp. 1993. 81-154. A váltójogról (XV. tc.), kereskedőkről (XVI. tc.), gyárak jogviszonyairól (XVII. tc.), közkereseti társaságokról (XVIII. tc.).

5 Jirkovsky, Sándor: Takarékpénztáraink 434.

6 Bariska, István: 150 éves a Kőszegi Takarékbank, 1844-1994. Kőszeg, 1994.; Köszegi, József: A kőszegi

Takarékpénztár száz éve. 1844-1944. Kőszeg, 1944.

7 Bariska, István: 150 éves; Köszegi, József: A Köszegi Takarékpénztár.

8 Baranya, Győr, Moson, Somogy, Sopron, Tolna, Vas, Veszprém, Zala megyék.

9 Bariska, István: Pénzintézetek és társadalmi környezetük a XIX. századi Kőszegen. In: Előadások Vas megye történetéből III. Szerk. Tilcsik, György. Vas megyei levéltári füzetek 9. Szombathely, 2000. 93-104.; Söptei, Imre: A Kőszegi Takarékpénztár kegyes és közhasznú adományai 1848 és 1896 között. In: Előadások Vas megye történetéből III. Edited by Tilcsik, György. Vas megyei levéltári füzetek 9. Szombathely, 2000. 105-112.
} 
pledge and $6 \%$ on loans without pledge. ${ }^{10}$ Apart from interest-bearing deposits and mortgage loans bill discounting was the most significant activity. ${ }^{11}$

Table 1: Savings banks operating in the Sopron administrative district in 1853

\begin{tabular}{|c|c|c|c|c|c|}
\hline \multirow{2}{*}{$\begin{array}{c}\text { Savings bank } \\
\text { headquarters }\end{array}$} & $\begin{array}{c}\text { foundation } \\
\text { date }\end{array}$ & \multicolumn{2}{|c|}{$\begin{array}{c}\text { amount of money } \\
\text { managed 31.12.1853 }\end{array}$} & \multicolumn{2}{|c|}{ annual profit in 1853 } \\
\cline { 3 - 6 } & & ranking & sum in C.M. & ranking & sum in C.M. \\
\hline Sopron & 1842 & 1st & $803,018.04$ & 4th & $17,760.51$ \\
\hline Kőszeg & 1844 & 2nd & $603,619.27$ & 1st & $83,097.41$ \\
\hline Veszprém & 1845 & 3rd & $481,245.55$ & 2nd & $66,378.13$ \\
\hline Pécs & 1845 & 4th & $409,230.50$ & 3rd & $32,798.38$ \\
\hline Győr & 1844 & 5th & $325,680.42$ & 7th & $4,182.04$ \\
\hline Szekszárd & 1846 & 6th & $200,707.16$ & 6th & $4,266.07$ \\
\hline Nagykanizsa & 1845 & 7th & $97,148.71$ & 5th & $15,588.39$ \\
\hline
\end{tabular}

Source: Jahres-Bericht der Handels- und Gewerbekammer in Oedenburg. 1853.

According to legal rules, savings banks were allowed to be involved in mortgage transactions of the banking transactions, could advance money to villages, pawn-shops, invest in treasury bonds, purchase shares issued by the central bank, and discount bills of exchange. ${ }^{12}$

István Széchenyi, in his work entitled Hitel [Credit], which is rightly considered as a milestone book, primarily called for the possibility of taking up high value loans considering that loans had already been available before the advent of modern financial institutions. Various city banks, religious and secular foundations provided short and long-term loans to customers seeking financial support, who were mainly borrowers living in or in the immediate neighbourhood of the settlement owning some kind of assets. Such assets could be land, a residential building, a shop or a parcel of land that could serve as security.

Even villages had lively lending activities, where primarily religious or secular foundations and orphan banks provided loans, which, considering the contemporary price levels and the amount of cash in circulation almost completely satisfied the private and institutional demand for loans. This institutional demand was made by the magistrates of the various settlements. ${ }^{13}$

During the era of Neo-Absolutism banks, likewise savings banks, were under governmental control, commissioners appointed to every savings bank were to ensure that operations were within the limits of the by-laws, and to make regular compliance reports. It was the government's intention to control the financial market through such commissioners. ${ }^{14}$

10 These restrictions on interest rates only ceased after 1861, when the Conference of the Justice of the Realm reenacted the old commercial laws.

11 Jahres-Bericht der Handels- und Gewerbekammer in Oedenburg an das hohe k. k. Ministerium für Handel, Gewerbe und öffentliche Bauten über den Zustand des Landes-Cultur der Handels-, Industrie- und Verkehrsverhaltnisse des Kammerbezirkes im Jahre 1853. Oedenburg, 1855. 230-231.

12 Jirkorsky, Sándor: Takarékpénztáraink 434-435.

13 Szabad, György: A hitelviszonyok. In: A parasztság Magyarországon a kapitalizmus korában. 1848-1914. Szerk. Szabó István. Bp. 1972. II. 184-245.; Kaposi, Zoltán: Uradalmi gazdaság és társadalom a 18-19. században. Bp.Pécs, 2000., Kóta, Péter: Áru és pénzhitel Körmenden a reformkorban. In: Előadások Vas megye történetéből III. Szerk. Tikcsik György. Szombathely, 2000.7-18.; Borsy, Judit: Gondoskodás az árvákról a pécsváradi közalapítványi kerület baranyai uradalmaiban a 19. század első negyedében. In: A földesurak szerepe. Dominium IV. Szerk. Szirácsik Éva. Unicus Múhely, Bp. 2018.186-211.; Halász, Imre: „.. . hatos kamatra...” Adatok Szombathely püspöki mezőváros hitelezési tevékenységéhez a neoabszolutizmus éveiben. In: Magyar Gazdaságtörténeti Évkönyv 20172018. Hitel - Bank - Piac. Szerk. Kövér, György - Pogány, Ágnes - Weisz, Boglárka. MTA Bölcsészettudományi Kutatóközpont; Hajnal István Alapítvány, Bp. 2018. 185-200.

14 Jirkovsky Sándor: Takarékpénztáraink 435. 


\section{Financial structure after the Compromise}

\section{The start}

Following the Compromise, ${ }^{15}$ the foundation of financial institutions gained new momentum and shortly a triple structure evolved consisting of banks, savings banks and mutual loan societies, which was soon supplemented by a fourth type of institution, when the land credit institution also commenced operation. ${ }^{16}$ Banks - or bank and credit institutions as they were referred to in contemporary statistics - founded in accordance with Act XVIII of $1840^{17}$ and operating in the form of companies limited by shares were obviously the most capital intensive. The Act remained effective until the Commercial Code of 1875 entered into force. In the 60s of the $19^{\text {th }}$ century, a few people's banks were also formed. Copying the German model, these people's banks were established for a determined period as stated in their by-laws - typically for twenty years - and primarily due to their name - were categorised among banks, but since their members had limited liability in most cases, which at most extended to the amount of their capital contributions, they in fact completed mutual loan society operations. ${ }^{18}$ Most of the people's banks subsequently transformed into savings banks.

Following Bach's Absolutism, the difference between banks and savings banks disappeared, their scope expanded thanks to Crédit Mobilier, the new type of bank invented and created by Émile and Isaac Pereire and spreading fast all over Europe, which combined the commercial and investment banking operations and expanded its activities to cover each and every area of the economic life. Its most important innovation was to raise capital not only by issuing promissory notes but also by accepting deposits similarly to savings banks. The banks springing up after 1867 introduced this then new approach and practice not only in the capital but also in larger provincial towns under the name of credit or industrial banks. At the county seat of Vas county the Commercial, Industrial and Agricultural Bank of Szombathely was an example of such a type of bank.

By 1865, one, the People' Bank of Vas-Zala (1865), then until the crisis of 1873 further three banks, namely the Commercial, Industrial and Agricultural Bank of Szombathely (1871), the Discounting Association of Szombathely (1871-1876), and the Credit and Discounting Institution of Sárvár (1872) had been established in the county. Following the crisis of 1873 mostly the establishment of financial institutions opting for the savings bank form gained incredible momentum from $1874 \mathrm{on}$. At the time, some of the former financial institutions were undergoing transformations, also choosing to become savings banks. At the end of 1874, in Vas county, already 20 companies limited by shares were in operation; their number grew tenfold in merely five years. The amount of paid-up share capital increased to F1 720,000, which is F1 674,000 rise in half a decade, while total deposit exceeded F1 7,000,000, which showed an increase of $\mathrm{Fl} 4,231,000$. Initially deposits were mainly passbook deposits, but soon current accounts appeared alongside them too. About a quarter of disbursed loans (F1 2,093,000) were short-term loans, mainly in the form of advances and bills of exchange, and three quarters were mortgage backed long-term loans (F1 5,558,000). Total annual turnover jumped to F1 $22,598,000$ already in the first year after the crisis, which is a F1 16,685,000 increase in five years.

\footnotetext{
15 A summary on the era: Kaposi, Zoltán: Magyarország gazdaságtörténete 1700-2000. Bp.-Pécs, 2002.

16 Kövér, György: Struktúrától a rendszerig. Pénzintézetek Magyarországon, 1873-1913. In: Kövér, György: A felhalmozás íve. Új Mandátum, Bp. 2002. 241-253.

17 Magyar Compass. Szerk.: Mihók Sándor. Bp. 1874. XXIII.

18 Magyar Compass 1874. 201.
} 
Table 2: Key indicators of Vas county savings banks as of 31.12.1874

\begin{tabular}{|c|c|c|c|c|c|c|c|}
\hline $\begin{array}{c}\text { Name of savings } \\
\text { bank } \\
\text { [settlement names } \\
\text { used after 1920] }\end{array}$ & $\begin{array}{c}\text { Foun- } \\
\text { dation } \\
\text { year }\end{array}$ & $\begin{array}{c}\text { No. of } \\
\text { issued } \\
\text { shares }\end{array}$ & $\begin{array}{c}\text { Share } \\
\text { capital }\end{array}$ & $\begin{array}{c}\text { Capital } \\
\text { coverage } \\
\text { ratio }\end{array}$ & $\begin{array}{c}\text { balance sheet } \\
\text { total as of } \\
31.12 .1874\end{array}$ & $\begin{array}{c}\text { net } \\
\text { profit }\end{array}$ & $\begin{array}{c}\text { per } \\
\text { share }\end{array}$ \\
\hline $\begin{array}{c}\text { Felsőőri } \\
\text { [Oberwart, A] }\end{array}$ & 1872 & 300 & 30,000 & 40 & 152,044 & 1,950 & 14.1 \\
\hline Hegyháti, Vasvár & 1873 & 500 & 25,000 & 50 & 27,437 & 2,000 & 12.5 \\
\hline Jánosházai & 1873 & 400 & 25,000 & 70 & 58,484 & 2,250 & F1 4.50 \\
\hline Kiscelli & 1869 & 250 & 50,000 & 51 & 426,249 & 9,064 & 37 \\
\hline Körmendi & 1871 & 300 & 30,000 & 40 & 203,455 & 4,808 & 30 \\
\hline Köszegi & 1844 & 300 & 31,500 & 100 & $2,345,064$ & 16,200 & 54 \\
\hline $\begin{array}{c}\text { Muraszombati } \\
\text { [Murska Sobota, } \\
\text { SLO] }\end{array}$ & 1873 & 150 & 30,000 & 50 & 36,976 & 1,432 & n.a. \\
\hline $\begin{array}{c}\text { Németnagy- } \\
\text { szentmihályi } \\
\text { [Grosspetersdorf, A] }\end{array}$ & 1872 & 300 & 30,000 & 60 & 77,987 & 1,320 & F1 4.40 \\
\hline $\begin{array}{c}\text { Németújvári } \\
\text { [Güssing, A] }\end{array}$ & 1872 & 600 & 30,000 & 40 & 106,504 & 3,960 & F1 6.60 \\
\hline $\begin{array}{c}\text { Pinkafói } \\
\text { [Pinkafeld, A] }\end{array}$ & 1870 & 300 & 30,000 & 50 & 445,633 & 1,800 & 12 \\
\hline $\begin{array}{c}\text { Rohonci } \\
\text { [Rechnitz, A] }\end{array}$ & 1873 & 300 & 30,000 & 50 & 94,362 & 1,800 & 12 \\
\hline Sárvári & 1869 & 300 & 60,000 & 40 & 321,327 & 5,400 & 12.5 \\
\hline Szentgotthárdi & 1871 & 300 & 30,000 & 40 & 272,636 & 2,277 & 18.1 \\
\hline Szombathelyi & 1873 & 150 & 30,000 & 50 & $1,548,955$ & 12,000 & 20 \\
\hline $\begin{array}{c}\text { Szombathelyi } \\
\text { Általános }\end{array}$ & 1873 & 600 & 60,000 & 52 & 151,831 & 1,867 & F1 3 \\
\hline Vas-Zalai, Körmend & 1874 & 500 & 50,000 & 30 & 37,424 & 1,481 & n.a. \\
\hline
\end{tabular}

Source: Magyar Compass, 1874. n. a. = not available

In the meantime the discounting institutions of Szombathely and Sárvár, respectively, expressed their transformation into savings banks in their names too, which at the same time brought about the expansion of their lines of business, among which bills discounting became just one albeit extremely significant operation.

In some settlements, competition appeared with the foundation of a second or even a third financial institution, which was already indicative of a budding microregional financial centre. We can most effectively illustrate the transformation process with the example of Körmend. Its first financial institute was the Self-Aid Society of Körmend Craftsmen (1865), the predecessor of the People's Bank of Vas-Zala, which was already named a 'people's bank'. This society was called the Self-Aid Society of Körmend from 1870, then from 1871 it continued its expansion and development under the name the Self-Aid Society and People's Bank of Körmend, and at its general meeting of 22 May 1873 it changed its name to the People's Bank of Vas-Zala, whose objective was to support the aims of commerce, industry and agriculture with long- and shortterm loans, obviously not barring private customers either. Shortly afterwards there appeared the second, the Savings Bank of Körmend (1871), then also the third financial institution, the 
Savings Bank of Vas-Zala (1874) in the manor centre situated at the intersection of major commercial roads. This latter merged into the People's Bank of Vas-Zala one and a half year later. Its emergence and transformation into a savings bank is a perfect example of a financial institution remaining profitable while developing in the centre of a regional market from a selfaid society into a savings bank within a decade.

The People's Bank of Vas-Zala reflects another feature of the initial decade: the emergence of a network of branches. This financial institution referring to its dual regionality (Vas and Zala counties) also in its name opened branches upon its foundation in Vas county in Vasvár, [Rába] Szenttamás, Ják, Németújvár [today Güssing], Muraszombat [today Murska Sobota], then later in Szombathely, of which the most significant one operated in Németújvár. In Zala county they opened branch offices in Alsólendva, Belatinc, then from 1882 in Zalaegerszeg, the Zala county seat. Thereby a contemporary banking market was created which realigned the regional market at the same time.

Apart from the above-mentioned, we are furthermore aware of the foundation of another branch. One of the first branches registered in the company registry documents was opened in Köszeg by the financial institution named the West-Hungarian Mortgage Bank in Sopron, which at the same time - although for a very limited amount of time - was the rival of the local savings bank. The by-laws of the bank founded with the initial capital of one million Austro-Hungarian forints (F1) and planning its operation for 60 years were approved on 22 June $1872,{ }^{19}$ and the company limited by shares embarked upon an extremely intensive bank development in Sopron from the very first moment. Subscription to their shares of F1 200 and script certificates of F 80 was approved by the Commodity and Stock Exchange of Pest. ${ }^{20}$ The new bank shortly opened a branch in Kismarton [Eisenstadt, A], ${ }^{21}$ then in Köszeg. Still in 1872, jointly with the local savings bank in Köszeg it became one of the share subscription institutions of Haza Life Insurance and Credit Bank..$^{22}$ And then happened a so far unknown event, which might have happened as an aftermath of the 1873 crisis; the regional court of Sopron registered the final dissolution of the bank in $1874,{ }^{23}$ while the termination of its branches in Pápa and Zalaegerszeg, respectively, had earlier been reported by the press. ${ }^{24}$ The bank's operations were terminated but the dissolution dragged on and the winding-up board invited shareholders to an extraordinary general meeting as late as 28 May 1883, where the board reported on the events to date and further opportunities. ${ }^{25}$

The Vas county savings banks springing up one after the other almost always demonstrate successful operations, even if competitors crop up at an odd settlement in the shape of a second or third savings bank. By the turn of the century the institutional network had expanded, and the operating profits were many times higher in 1899 than those a quarter century earlier.

The gold-based Krone was introduced in 1892 as part of the currency reform, ${ }^{26}$ and the law set the value of the new Krone at half a forint. Since the circulation of the Austro-Hungarian Forint was not tied to deadlines, only from 1 January 1900 was it mandatory to publish data in Krone, so in the balance sheets of 1899 both currencies were used. ${ }^{27}$

\footnotetext{
19 This was also reported by the press: Magyar Újság, 1872. június 27.

20 Budapesti Közlöny, 1872. szeptember. 4. 1608.

21 Pesti Napló, 1872. október 2.

22 Advertisements in several issues of the Ellenőr, the Hon, the Pesti Napló and the Magyar Újság, the Vasárnapi Újság, and Magyarország and Nagyvilág in December 1872.

23 Központi Értesítő, 1877. február 17. Date of the court resolution on registration: 1876. augusztus 5.

24 Budapesti Közlöny Hivatalos Értesítője, 1873. augusztus 7.

25 Budapesti Közlöny, 1883. május 2.16.; május 3. 12.; május 5. 12.p.

26 1892. évi XVII. tc.

27 Magyar Compass 1900/1.
} 
Table 3: Savings banks of Vas county as of 31.12.1899

\begin{tabular}{|c|c|c|c|c|c|c|}
\hline $\begin{array}{l}\text { Name of savings bank } \\
\text { [settlement names } \\
\text { used after 1920] }\end{array}$ & $\begin{array}{l}\text { currency } \\
\mathrm{F} 1 / \mathrm{K}\end{array}$ & $\begin{array}{c}\text { founding } \\
\text { date }\end{array}$ & $\begin{array}{l}\text { initial } \\
\text { capital } \\
\text { thousand } \\
\text { Fl/K }\end{array}$ & $\begin{array}{c}\text { balance } \\
\text { sheet total }\end{array}$ & $\begin{array}{c}\text { net } \\
\text { earnings }\end{array}$ & $\begin{array}{l}\text { total } \\
\text { turnover }\end{array}$ \\
\hline Felsőőri [Oberwart, A] & $\mathrm{F} 1$ & 1872 & 60 & $1,267,468$ & 14,755 & $2,975,459$ \\
\hline Felsőőri Járási & $\mathrm{K}$ & 1894 & 60 & 476,045 & $200 \mathrm{~K} / \mathrm{r}$ & $1,802,348$ \\
\hline Felsőőri Általános & $\mathrm{K}$ & 1894 & 60 & & 140 & 1537780 \\
\hline $\begin{array}{c}\text { Gyanafalva } \\
\text { [Jennersdorf, A] }\end{array}$ & $\mathrm{F} 1$ & 1891 & 30 & 632,227 & 10,118 & n.a. \\
\hline Jánosházi & $\mathrm{K}$ & 1873 & 35 & 806,205 & 14,481 & \\
\hline Jánosháza Vidéki & $\mathrm{K}$ & 1896 & 50 & 683,990 & 11,758, & $6,012,485$ \\
\hline Kemenesaljai, Kis Cell & $\mathrm{K}$ & 1889 & 40 & $1,085,308$ & 13,094 & $8,330,958$ \\
\hline $\begin{array}{l}\text { Kemenesaljai Közgazda- } \\
\text { sági Hitelbank, Kis Cell }\end{array}$ & $\mathrm{K}$ & 1893 & 300 & $1,904,494$ & 33,750 & $18,721,395$ \\
\hline Körmendi & $\mathrm{K}$ & 1871 & 60 & $2,563,908$ & 34,073 & $6,880,341$ \\
\hline $\begin{array}{l}\text { Vas-Zalamegyei Első, } \\
\text { Körmend }\end{array}$ & $\mathrm{K}$ & 1865 & 200 & 710,826 & 683 & $3,056,628$ \\
\hline Körmendi Általános & $\mathrm{K}$ & 1895 & 100 & 924,322 & 18,097 & $8,373,544$ \\
\hline Kőszegi Takarékpénztár & $\mathrm{F} 1$ & 1844 & 120 & $5,736,305$ & 78,779 & $5,090,440$ \\
\hline Kőszegi Általános & $\mathrm{Fl}$ & 1876 & 25 & 717,740 & 5,827 & $1,948,139$ \\
\hline $\begin{array}{c}\text { Pinkavölgyi, } \\
\text { Monyorókerék [Eberau A] }\end{array}$ & $\mathrm{K}$ & 1898 & 130 & 238,030 & 6,891 & 941,041 \\
\hline $\begin{array}{c}\text { Muraszombati [Murska } \\
\text { Sobota, SLO] }\end{array}$ & $\mathrm{F} 1$ & 1873 & 60 & 927,811 & n. a. & $2,325,879$ \\
\hline $\begin{array}{l}\text { Délvasmegyei, } \\
\text { Muraszombat }\end{array}$ & $\mathrm{Fl}$ & 1884 & 50 & 409,350 & 10,050 & $1,635,365$ \\
\hline $\begin{array}{c}\text { Muraszombati } \\
\text { Mezőgazdasági Bank }\end{array}$ & $\mathrm{K}$ & 1898 & 160 & 320,087 & 3,384 & $2,656,845$ \\
\hline $\begin{array}{c}\text { Németszentmihályi } \\
\text { [Grosspetersdorf, A] }\end{array}$ & $\mathrm{Fl}$ & 1872 & 60 & 605,002 & 7,420 & $1,102,782$ \\
\hline Németújvári [Güssing, A] & $\mathrm{F} 1$ & 1876 & 30 & 523,101 & 8,569 & 468,666 \\
\hline $\begin{array}{c}\text { Németujvári takarék- } \\
\text { és hitelpénztár }\end{array}$ & $\mathrm{K}$ & 1894 & 40 & 176,114 & 3,493 & 529,646 \\
\hline Őrségi, Ôriszentpéter & $\mathrm{Fl}$ & 1892 & 30 & 209,325 & 5,010 & 910,031 \\
\hline Pinkafői [Pinkafeld, A] & $\mathrm{F} 1$ & 1870 & 60 & 781,611 & 3,166 & $1,652,832$ \\
\hline $\begin{array}{c}\text { Pinkafői Községi } \\
\text { Hitelpénztár } \\
\end{array}$ & $\mathrm{K}$ & 1872 & 60 & $2,018,934$ & n. a. & $3,041,930$ \\
\hline Rohonczi [Rechnitz, A] & $\mathrm{F} 1$ & 1873 & 30 & 407,297 & 6,261 & $1,526,093$ \\
\hline Sárvári Első & $\mathrm{F} 1$ & 1868 & 60 & $1,550,868$ & 18,425 & $4,207,715$ \\
\hline Sárvárvidéki & $\mathrm{K}$ & 1872 & 80 & 801,250 & 8,790 & $5,924,111$ \\
\hline Szentgotthárdi & $\mathrm{K}$ & 1871 & 60 & $2,898,558$ & 24,612 & $5,040,148$ \\
\hline $\begin{array}{l}\text { Rába-Lapincsvölgyi, } \\
\text { Szentgotthárd }\end{array}$ & $\mathrm{F} 1$ & 1882 & 60 & 311,321 & 3,097 & $1,686,381$ \\
\hline Szentgotthárdi Általános & $\mathrm{F} 1$ & 1892 & 60 & 979,246 & 11,795 & $2,823,162$ \\
\hline
\end{tabular}




\begin{tabular}{|c|c|c|c|c|c|c|}
\hline Szombathelyi & $\mathrm{F} 1$ & 1867 & 120 & $4,451,659$ & 57,012 & $17,844,643$ \\
\hline Szombathelyi Általános & $\mathrm{F} 1$ & 1872 & 60 & $2,289,037$ & 25,173 & $7,654,003$ \\
\hline Vas megyei, Szombathely & $\mathrm{K}$ & 1885 & 68 & $2,361,863$ & 24,777 & $10,098,858$ \\
\hline Szombathely Városi & $\mathrm{K}$ & 1893 & 120 & $1,231,955$ & 11,677 & $5,701,273$ \\
\hline $\begin{array}{c}\text { Mezőgazdasági Takarék- } \\
\text { és hitelbank Szombathely }\end{array}$ & $\mathrm{K}$ & 1897 & 500 & $1,328,066$ & 38,960 & $47,016,203$ \\
\hline Hegyháti, Vasvár & $\mathrm{F} 1$ & 1873 & 25 & 416,483 & 10,804 & $2,198,689$ \\
\hline Vasvári & $\mathrm{F} 1$ & 1897 & 40 & 254,187 & 6,779 & $1,427,239$ \\
\hline Vép és Vidéke & $\mathrm{K}$ & 1896 & 60 & 101,077 & 2,084 & n.a. \\
\hline
\end{tabular}

Source: Magyar Compass, 1900/1.

Three lines of business, i.e. accepting deposits, bill discounting and mortgage transactions, were among the services of almost every savings bank. They generally paid a $4 \%$ interest on deposits, except for the Savings Bank of Szombathely, which set this value between 3-4\%, and there were some savings banks operating at the county seat (the General Savings Bank of Szombathely] and the Savings Bank of Vas county) that assumed the interest tax from its customers in the interest of attracting more business. This could only be done by high-turnover financial institutions. In the period leading to the turn of the century, almost every savings bank had outstandingly high proportions of deposit and mortgage transactions and profits generated on them in their balance sheets. Bill discounting was one of the most significant operations at the great majority of the savings banks, or often the most significant one, generally with a $6 \%$ margin. Some savings banks still offered different conditions to their customers: the Savings Bank of Körmend], for example, paid a 7.5-8\% interest on 3-4-month terms. However, very few financial institutions offered rediscounting services (e.g. the Savings Bank of RábaLapincsvölgy in Szentgotthárd). In case of mortgage loans the lowest margin is $5.5 \%$ (at the Savings Bank of Felsőőr and the freshly founded Agricultural Bank of Muraszombat). Generally $6 \%$ was charged on 10-year loans, and $6.5 \%$ on 20-year ones (Gyanafalva), both savings banks in Jánosháza charged 7\% on 10-year loans, while at the Savings Bank of Körmend the basis for the $6.5 \%$ interest loans was one hundred times its customer based tax. The Savings and Credit Bank of Németujvár offered loans for 30 years at 7\%, the First Savings Bank of Sárvár charged 6-7\% up to half the value of the security or for 10 years, while the General Savings Bank of Szentgotthárd charged $6.5 \%$ on 20 -year loans.

Later debentures appeared - their turnover was outstandingly significant at the Savings Banks of Németszentmihály and Németújvár - amounting to F1 102,679 at the latter, which made this line of business the second most successful one in 1899 following mortgage loans. This is when trade in securities also entered the scene. In their balance sheets the banks recognised the volume of treasury bills among their assets. At the county seat, at the Savings bank of Szombathely F1 214,750 out of F1 389,645, at the General Savings Bank of Szombathely, F1 58,010 out of Fl 111,281, in one of the district seats, at the Savings Bank of Kemenesalja, treasury bills amounted to 41,400 out of their assets of K 63,310, while at the Savings Bank of Pinkavölgy, treasury bills represented only K 50 out of K 1550 . No separate data was registered by the smaller financial institutions, but we cannot rule out the possibility that they recognised securities under advance payments. They generally granted advances on securities, goods and crops and precious metals up to three-quarters of the assessed value. In the case of securities it was typically up to three quarters of their par value at an $8 \%$ interest. The situation was the same for mortgage loans.

People could make deposits at most savings banks, with the Economic Credit Bank of Kemenesalja, the Savings bank of Körmend] and the Savings Bank of Vas county among them, 
while collateral transactions were only shown separately in the balance sheet of the Savings Bank of Köszeg; here they also granted loans up to three-quarters of the assessed value at a $6 \%$ interest rate.

When a co-operative savings association or self-aid society transformed into a savings bank, shares had to be issued to replace unit certificates. In the first step, the value of unit certificates had to be increased and their value was generally bolstered with money from the reserves and annual dividends. For example, the Savings Bank of Pinkavölgy increased the value of each 40-forint unit certificate to 50 forints and offered a new 50-forint share for two old 50-forint unit certificates. The same happened at the Savings Bank of Rohonc, where they finally issued 200-krone shares. If not completely the same, but a similar process was adopted to increase the capital of the Savings Bank of Muraszombat, where, at the end of the transaction, they completed a share swap too.

The Village Credit Bank of Pinkafo,, which retained its former ownership structure, is a unique example, where every house owner had a right to vote. Another unique service was rendered by the First Savings Bank of Sárvár, which provided self-aid society loans at a 5\% interest based against weekly deposits.

\section{The savings banks of Szombathely}

The financial institutions of the county seat with 16,000 residents, which had become a major administrative and economic centre by the turn of century, must be considered separately. After a modest start before the crisis of 1873 , by the turn of century already five successful banks - with differing capital intensities - had been in operation in the town, with the AustroHungarian Bank also entering its financial scene. The terms of the almost ubiquitous four lines of business (deposit transactions, bill discounting, mortgage loans and advancement) were similar in Szombathely to those of the other Vas county savings banks, although depending on the amount placed or loaned the interest margin could change. The differences in lines of business between the financial institutions operating at the county seat can be spotted when services other than the core ones are considered.

The Savings Bank of Szombathely offered mortgage loans for 10, 23 or 32-year terms, while the General Savings Bank of Szombathely did so for 10 years but customers were also allowed to repay the loan in instalments, in which case the interest rate was lower (6\%). Advancement was generally realised on securities up to $75 \%$ of the assessed value and the city savings bank also offered collateral loans. The Austro-Hungarian Bank established official relations with the Savings Bank of Szombathely, which also discounted the bills of exchange of the AustroHungarian Bank for 1\% commission. The General Savings Bank of Szombathely operated a savings association, the Savings Bank of Vas County also dealt in securities, accepted deposits and also managed current account transactions. The City Savings Bank of Szombathely not only acted as a deposit bank, but also dealt in securities. This bank was the successor of the Commercial, Industrial and Agricultural Bank of Szombathely, which was wound up in 1893 and then re-established under this name. ${ }^{28}$ The widest range of services was offered by the Agricultural Savings and Credit Bank, which offered bill discounting, overdraft facilities, securities and property sales as part of their portfolio besides its four core services, and even bought and sold all types of commodity though chiefly completed warehousing operations.

${ }_{28}$ Kunc, Adolf - Kárpáti, Kelemen: Szombathely - Savaria rend. tanácsú város monographiája. II. Szombathely, 1894. 528.; Magyar Compass 1892-93. 400. 
Table 4: Key data of savings banks in Szombathely as of 31.12.1899

\begin{tabular}{|c|c|c|c|c|c|c|c|c|}
\hline \multirow{3}{*}{$\begin{array}{l}\text { Name and } \\
\text { founding date of } \\
\text { the savings bank }\end{array}$} & \multirow{3}{*}{ currency } & \multirow[b]{2}{*}{$\begin{array}{l}\text { initial } \\
\text { capital }\end{array}$} & \multirow{2}{*}{$\begin{array}{c}\text { annual } \\
\text { turnover } \\
1899\end{array}$} & \multirow{2}{*}{$\begin{array}{l}\text { annual } \\
\text { profit } \\
1899\end{array}$} & \multicolumn{4}{|c|}{ lines of business } \\
\hline & & & & & deposit & $\begin{array}{l}\text { bill dis- } \\
\text { counting }\end{array}$ & $\begin{array}{c}\text { mortgage } \\
\text { loans }\end{array}$ & $\begin{array}{c}\text { Advance- } \\
\text { ment }\end{array}$ \\
\hline & & \multicolumn{3}{|c|}{ thousand $\mathrm{Fl} / \mathrm{K}$} & \multicolumn{4}{|c|}{$\%$} \\
\hline $\begin{array}{c}\text { Savings Bank } \\
\text { of Szombathely } \\
\text { 1867, the } \\
\text { contractual partner } \\
\text { of the Austro- } \\
\text { Hungarian Bank }\end{array}$ & $\mathrm{F} 1$ & 120 & 17,844 & 57.0 & $3-4$ & $6-6.5$ & $5.76-6$ & 6 \\
\hline $\begin{array}{c}\text { General } \\
\text { Savings Bank of } \\
\text { Szombathely, } 1872\end{array}$ & $\mathrm{~F} 1$ & 60 & 7,654 & 25.1 & 4 & $6-6.5$ & 10 and 6 & 6.5 \\
\hline $\begin{array}{c}\text { Savings Bank } \\
\text { of Vas County } \\
1885\end{array}$ & $\mathrm{~K}$ & 68 & 10,098 & 24.7 & 4,5 & $6-7$ & 6 & n.a. \\
\hline $\begin{array}{c}\text { City Savings Bank } \\
\text { of Szombathely, } \\
1893\end{array}$ & $\mathrm{~K}$ & 120 & 5,701 & 11.6 & 5 & $\begin{array}{l}6 \\
6.5 \\
6.75\end{array}$ & $6-7$ & $7-8$ \\
\hline $\begin{array}{c}\text { Agricultural } \\
\text { Savings and Credit } \\
\text { Bank, } 1897\end{array}$ & $\mathrm{~K}$ & 500 & 47,016 & 38.9 & 4 & $5-6$ & yes & 6 \\
\hline
\end{tabular}

Source: Magyar Compass, 1900/1.

In Vas county between 1878 and 1899 the number of financial institutions increased to nearly two and a half times, in settlements with populations between one thousand and three thousand, two, in larger settlements, three, and at the county seat five financial institutions were established by the turn of century. The amount of the initial capital increased by nearly eleven times, the balance sheet total figures 6.3 times, and the total turnover of Vas county financial institutions amounted to K 178,414,263 in 1899. Within the county's territory smaller microregional financial markets emerged. So far we have not found data related to transactions that undoubtedly existed between such markets.

If we compare the situation in Vas county to the capital accumulation processes that underwent in Southern Transdanubia, we can see the most intensive and dynamic development in Vas county.

Table 5: Key data of financial institutions in Southern Transdanubian counties as of 31.12.1899 The amounts are presented here in the currency stated in the balance sheet.

\begin{tabular}{|c|c|c|c|c|}
\hline county & $\begin{array}{c}\text { number of } \\
\text { saving banks }\end{array}$ & $\begin{array}{c}\text { initial capital } \\
\mathrm{K} \\
1899\end{array}$ & $\begin{array}{c}\text { balance sheet total } \\
\text { (profit) F1/K } \\
1899 \\
\text { n.a.: } 5\end{array}$ & $\begin{array}{c}\text { Cumulative annual } \\
\text { turnover } \mathrm{F} 1 / \mathrm{K} \\
1899\end{array}$ \\
\hline Baranya & $\begin{array}{l}\text { 1878: } 9 \\
\text { one of which is } \\
\text { under liquidation } \\
\text { 1899: } 9\end{array}$ & $\begin{array}{c}1,450,000 \\
\text { (of which Pécs } \\
1,000,000)\end{array}$ & $\begin{array}{c}\text { 16,870,694 } \\
(246,975) \\
\text { (of which Pécs } \\
13,138,039 \text { ) }\end{array}$ & $\begin{array}{c}78,780,217 \\
\text { (of which Pécs } \\
58,498,855 \text { ) } \\
1 \text { is missing }\end{array}$ \\
\hline
\end{tabular}




\begin{tabular}{|c|c|c|c|c|}
\hline Somogy & $1878: 6$ & F1 970,000 & F1 3,660,249 & F1 20,398,148 \\
& $1899: 16$ & K 890,000 & $\begin{array}{c}(108,505) \\
\text { K 15,793,916 } \\
(309,851)\end{array}$ & K148,580,829 \\
& & & F1 9,538,566 & F1 37,363,468 \\
& $1878: 10$ & F1 765,000 & (F1 162,198) & K 40,220,897 \\
Tolna & $1899: 17$ & K 630,000 & K 6,251,258 & \\
& & & (K 104,240) & \\
\hline Vas & $1878: 16$ & K 2,648,000 & K 31,730,342 & K 178,414,263 \\
& $1899: 37$ & & ( 376,094) & \\
\hline Zala & $1878: 9$ & F1 1,410,000 & F1 26,368,298 & F1 128,323,735 \\
& $1899: 27$ & K 2,160,000 & K 9,483,760 & K 44,720,348 \\
\hline Total & $1878: 51$ & F1 4,595,000 & F1 56,437,807 & F1 193,963,368 \\
& $1899: 89$ & K 3,680,000 & K 31,528,934 & K 233,522,074 \\
\hline
\end{tabular}

Source: Magyar Compass, 1879.; Magyar Compass, 1900/1.

\section{Mutual loan societies}

We can also categorise mutual aid and self-aid societies among mutual loan societies. Their role is not negligible since in the subsequent decades these societies would transform into people's banks or mutual loan societies en masse all over Hungary. However, in the middle of the 1870s we are still at the beginning of the process. ${ }^{29}$ These mutual loan societies were established and operated in accordance with Sections 223-230 and 247-250 of the Commercial Code ${ }^{30}$; their liability could be limited or unlimited, and their term could be determinate or indeterminate. Their initial capital was not made up of shares, but of capital contributions or unit certificates. ${ }^{31}$ We only have sporadic data regarding the number and business data of mutual loan societies for the whole of the historic Hungary. We are aware of several mutual loan societies that must have been in operation but did not report their key data. They collected deposits, made reserves and granted loans against bills or promissory notes. From the end of 1874 we have data about five mutual loan societies operating in Vas county, which are the First Mutual Aid Society of Jánosháza (1874), the Civil Mutual Aid Society of Jánosháza (1871), The Self-Aid Society of Magyargencs-Hőgyész (1874), the Mutual Aid Society of Pinkafó (1873), and the Mutual Aid Society of Szombathely (1873). Of them, the societies of Pinkafó and Magyargencs-Hőgyész reported net profits, the former F1 1,381 and the latter F1 708. ${ }^{32}$ In the 1890 s already thirty mutual loan, mutual aid or self-aid societies were in operation in the following settlements: Alhó, Barkóc, Borostyánkő, Bottyánd, Csönge, Csörötnek, Egervár, Felsőlövő [Oberschützen], Gór, Halmos, Ják, Jánosháza, Kemenesszentpéter, Kukmér, Lapincsvölgy, two in Magyargencs (the Savings and Mutual Aid Societies of Magyargencs-Hőgyész and Magyargencs, respectively), Nagynémetszentmihály, Nemesmagasi, Nádasd, Németszentgrót, Németújvár, Ölbő, Pinkafö, Pinkavölgy, Pusztaszentmihály, Rábakeresztúr, Rohonc and Vönöck. ${ }^{33}$

\footnotetext{
Magyar Compass 1873.60.

1875. évi XXXVII. tc.

Magyar Compass 1874. 237-265.

Magyar Compass 1875. 256.; 259.; 264; 272.

MNL VaML VII.1.h.
} 